\title{
The Corporate Crime Liability for Environmental Pollution
}

\author{
Hadi Purnomo \\ Student at Doctoral Program of Law \\ Universitas Borobudur \\ Jakarta, Indonesia \\ hadipurnomoraden@gmail.com
}

\author{
Faisal Santiago \\ Faculty of Law \\ Universitas Borobudur \\ Jakarta, Indonesia \\ faisalsantiago@borobudur.ac.id
}

\begin{abstract}
En vironmental pollution resulting in damage to the quality of the environment, will certainly reduce the carrying capacity of the environment. The reduced carrying capacity of the environment results in reduced human environmental benefits. Potential environmental issues that can affect the sustainability of nature and human health raises awareness of the need for regulation of environmental problems with the law. This paper will discuss how the responsibility of corporations in environmental management.The Central Government through the Ministry of Environment and Forestry make collaboration with the Regional Government and related agencies. They must work extra in terms of supervision of the Environmental Corporations by providing continuous coaching, efficient, and integrity in the hope of reducing the percentage of environmental crime committed by corporations.
\end{abstract}

Keywords - accountability, corporate crime, environmental pollution

\section{INTRODUCTION}

Environ mental pollution directly or indirectly can reduce the quality of the environment, even in turn can lead to destruction of biotic and abiotic communities. Humans as one component of biotic can also be affected by environmental pollution either directly or indirectly. Environ mental pollution resulting in damage to the quality of the environment, will certainly reduce the carrying capacity of the environment. The reduced carrying capacity of the environment results in reduced human environmental benefits. Even not only environmental pollution often result in reduced environmental carrying capacity but it also cause certain diseases in humans because humans consume food produced from the environment that has been contaminated. Even the disease arises as a result of inhaling polluted air, or drinking water that has been contaminated and so on. Thus environmental pollution also affects human health. Besides causing environmental damage, environmental pollution are decreasing environmental carrying capacity, threatening human health and the sustainability of the environment itself.

Whereas the survival of human life depends on the resources available both biotic and abiotic. Therefore, it is necessary to think about how to manage resources that can preserve the environment. In the context of development, known the concept of sustainable development. Indeed the concept of sustainable development, has been laid as a policy, but in practice experience all this time, precisely happened the processing of natural resources that are not controlled with the environmental da mage that disrupt nature conservation. In connection with that, in the framework of utilization of natural resources to promote the general welfare as contained in the 1945 Constitution and to achieve the happiness of life based on Pancasila, efforts should be made to preserve the harmonious and balanced environmental capability to support development oriented to the welfare of the people.

An environmentally sound development that is then popularized by sustainable development by World Commission on Environment and Development is defined as development aimed at meeting the needs of the present generation without sacrificing the interests and needs of future generations[1]. The main prerequisites of environmentally sound development are the fulfillment of humanneeds, maintenance of ecolocigal integrity, social equity and self determination[1].

Besides the principles of environmentally sound development there is also the principle of good environmental governance. Given the principles of good environmental governance, it will naturally bind to any activity that has an impact on the environment. Industrial development as one of the pillars of national development, will not be separated from the principles mentioned above. Industrial activity in its implementation, although in its establishment it is equipped with standard of environmental management, but in its journey not a few that leave environmental problems.

Potential environmental issues that can affect the sustainability of nature and human health raises awareness of the need for regulation of environmental problems with the law. The regulation of environmental issues in Indonesia begins with the existence of the Environmental Law, No. 4 of 1982 on Basic Provisions on Environmental Management (State Gazette of 1982 No. 12 supplement to State Gazette No. 3215) which in its development is enhanced and replaced by Law No. 23 of 1997 on Environmental Management and the latest by Law No . 32 of 2009 on the Protection and Management of the Environment.

The Law on Basic Provisions on Environmental Management and the Law on Environmental Management and the Law on Environmental Protection and Management essentially provides protection to biotic communities and abiotic communities in order to avoid pollution caused by human activities themselves. The protection of the law, 
among others, is provided by giving criminal sanction to the perpetrator of environmental crime.

Furthermore, activities that could potentially lead to a reduction in environmental carrying capacity or environmental pollution are essentially not merely human activities, but corporate activities. Therefore, the protection of the community by giving criminal sanction to the perpetrator of the environmental crime shall not only give criminal sanction to the subject of human law but also give criminal sanction to the subject of corporate law or known as corporate criminal liability.

\section{PROBLEM}

This paper will discuss about: how is corporate responsibility in environmental management?

\section{DISCUSSION}

The term pollution as a technical term in Indonesian is a new term. In the old dictionaries such as dictionary W.J.S Poerwadarminta (1954) there is indeed encountered such term polluted, pollute, polluted and so forth. But the word pollution is not found. This term began to be used since 1970. According to Aprilani Soegiarto The term "pollution" began to be used for the first time to translate the meaning of the term foreign "pollution" at seminar Biology II at Ciawi Bogor in 1970. Since the first spark in Ciawi it appears that the use The term "pollution" is beginning to spread and evenly in the Indonesian language that is expanding. The term "pollution" has even been used in the official speech of the Head of the Republic of Indonesia before the House of Representatives on 16 August 1972, in Five-Year Development Plan (REPELITA) II: 1974 / 75-1978 / 79 on Article 244 the term "pollution" appears to be used in the sense agreed at the Seminar Biology II at Ciawi Bogor in 1970. And through REPELITA II it became increasingly widespread use and its use in conversations and writings Concerning corporations as a subject of criminal law is still a novelty. Corporations as subjects of criminal offenses, especially developed by the existence of crimes involving corporations as subjects of criminal acts, caused by the influence of the rapid development of the national business world. In Indonesia, in its legislation, it has emerged and is known as a corporation legal entity as the subject of criminal offense in 1951, namely in the Law on Stockpile of Goods and became widely known in Law no. 7 Drt Year 1955 on Economic Crime[2].

In general, however, as contained in the Criminal Code (Article 59 of the Criminal Code), the subject of corporate crime is not yet known, and which is recognized as a subject in the criminal offense in general is "person". A corporation is a term commonly used by criminal and criminology lawyers to name a legal body (rechtpersoon), legal body or legal person. The concept of legal entity that originated from the concept of civil law that grew out of the development of society. Corporations can be divided based on the kinds, types, and nature. According to its kind, legal entities (corporations) can be distinguished from original legal entities (pure, original) and legal entities that are not original. By type, legal entities can be divided into public corporations, and private corporations. Meanwhile, by its nature, legal entities can be divided into corporations (corporatie) and foundations (stichting).
In the criminal law literature, there are several theories of corporate criminal liability which are known as follows:

\section{Theory of identification.}

In Anglo-Saxon countries like Britain, in criminal liability criminal liability has been known the concept of direct corporate criminal liability or known as criminal liability doctrine directly [3]. In the sense of this theory, firms can do offense directly through people who are closely related to the company and are viewed as the company itself, they are not a substitute and therefore the accountability of the company is not personal liability. This theory is known as the theory of identification. With regard to the need for mens rea in a crime, the judge has developed a means of linking the mind with this legal entity, confirming the opinion that the company is criminally responsible in such a case. They have done so based on identification theory. Since the company is an artificial entity, it can only act through its agents. According to the theory of identification, certain agents in a company are considered as "directing mind" or "alter ego". Mens rea individuals are then associated with the company. If the individual is authorized to act on behalf of and during the business of the enterprise, then the "mens rea" of individuals is the "mensrea" of the enterprise [4]. In identification theory, the company is res ponsible for criminal acts committed by senior officials within the company as long as they do within the scope of authority or in the affairs of the company's transactions.

\section{The theory of vicarious liability (vicarious liability).}

A simple substitute criminal liability can be said to be a person's accountability for an act done by another person. Relevant to vicarious liability problems, the principle of "employment principle" has evolved. In this principle the main responsibility of the actions of the workers / employees who perform the act within the scope of task / work. In Australia there is no doubt that "the vicar's criminal act" and "the vicar's guilty mind" can be attributed to the employer or principal. This is contrary to what happened in England. "A guilty mind" can only be linked (with the employer) if there is a delegation of relevant authority and obligations (a relevant "delegation" of powerand duties) by law "[5].

\section{Strict liability criminal liability theory (strict liability).}

When viewed from its history, the birth of criminal liability on the basis of errors or liability on foult or negligence or foult liability, is a reaction to the model of absolute liability or strict liability that apply in antiquity. In its development, the law begins to pay more attention to the things of execuratory considerations and, as a result of the "moral philosophy" influence of religious teachings, tends to lead to the recognition of "moral culpability" as a fixed basis for unlawful acts, the principle of absolute responsibility as a punishment necessary to avoid the act of revenge then turns into responsibility based on the existence of the "error" element. In addition to these moral teachings, another important factor in the process of changing attitudes is the belief that the loss of a "negligence" is by no means less important than the harm resulting from intent. The ones included in the definition of "mistake" are both deliberate acts or omissions. Thus, the original moral responsibility becomes the legal liability [6]. According to E. Sefullah Wiradipradja, the theory of absolute liability or liability without foult or also known as absolute liability or strict liability, is the responsibility without necessity to prove the 
existence of a mistake. Or in other words, it is a principle of responsibility that views "mistakes" as irrelevant to question whether or not they are in fact present [6].

Pollution Responsibility and Environmental Destruction in Criminal Legal Aspect.

Talks of indemnity can not be separated from the responsibility of the perpetrators of pollution and environmental destruction. Article 88 of the Environmental Protection and Management Law stipulates: "Any person whose actions, activities and / or activities use hazardous and toxic substances, produce and / or manage hazardous and toxic waste, and / or poses a serious threat to the environment life is ultimately responsible for the losses that occur without the need to prove the element of error. "

The article contains a principle called "strict liability" or in the words of Komar Kantaatmadja "the principle of absolute responsibility". According to the term of Munadjat Danusaputra, the principle of direct and immediate responsibility, namely the obligation to pay compensation arises immed iately / instantaneous the occurrence of losses by not questioning the wrong, the cause of the loss. However, according to Kusnadi Hardjasoemantri of the words "in some relating to certain types of resources" means that the absolute responsibility is not generally applicable. Legislation will further regulate the types of categories of activities that will be affected by such provisions.

The system of accountability is a departure from the absolute liability system known in our civil law by using arbitrary unlawful patterns of tortious liability of the system based on fault. Based on this legal principle, whenever a person will indemnify him, then he is obliged to prove in advance that the actions of the other party are causing harm to him. The obligation to prove it lies first to those who want to demand redress. If it fails to prove it, the claim for compensation will not be met.

Why is in the case of environment used this strict liability system? There are actually some considerations about it. First, because the principle of "liability based on fault" that is used contains a proving process that incriminates the patient. He will only get compensation if successfully proves the element of error from the defendant. While the reality in the case of environmental pollution most people / plaintiffs do not understand the behavior of modern technology, whereas on the other hand pollutants / defendants are industrialists / entrepreneurs master the information and behavior of the industries they manage with the resulting production. So the plaintiff will always be in a weak position that will not be able to carry out his demands because of dealing with the defendant who has a strong position.

Curzon then mentions several reasons why the use of "strict liability" (in criminal law) as follows: 20

a. It is essential to guarantee compliance with certain important rules necessary for the welfare of the people.

b. Proof of a mistake will be very difficult for violations related to the welfare of the community.

c. The high level of "social hazard" caused by the action concerned.

The strict liability principle in our country has already been adopted by the ratification of the International
Convention on Civil Liability for Oil Pollution Damage (1969) or the international convention on civil liability in the destruction of ocean by oil or otherwise commonly abbreviated to Civil Liability Convention (CLC) 1969 with Presidential Decree No. 18 of 1978. It is hereby affirmed that in addition to what is specifically determined, in the event of an accident or in the event of an accident comprising a sequence of events at the first instance, the shipowner shall be liable for any damages caused by pollution due to oil exit or vomited from the ship as a result of an accident. The only exception is when the shipowner can prove that immediate aand instant responsibility does not happen to him. Here the obligation to prove exactly the opposite is placed on the party who must pay compensation, while the party who demands compensation is enough to just show the facts.

The strict liability principle in this CLC is exempted in the following matters:

a. If an accident arises because of war, armed conflict of civil war, rebellion or natural disaster that can not be avoided.

b. If an accident is caused by an act or omission of a third party in order to incur such loss.

c. If the accident is caused by the act or omission of the victim hims elf.

In this case it is intended to be able to include two possibilities

1) Accidents are caused by acts or omissions from the coastal State responsible for the maintenance of lighthouses and other navigational instruments.

2) If the shipowner can prove that the accident arose because of an act or omission by the party suffering his own loss.

Notwithstanding this discussion of "strict liability" as also mentioned above is the question of the established system of evidence. For this purpose is usually used what is called "reversed proof material" as a deviation from the principle of presumption of innocence which is widely adopted now. With this reversal, the burden of proof does not become a burden for the victim of libel for litigation before the court as a plaintiff, because here it is the responsibility of the defendant to prove that his activities have the risks of not having harmful consequences or causing disruption in the form of pollution or environmental destruction. Thus, in the case of the environment one is responsible for the consequences of loss, except when he can prove that he can not be blamed.

In Law Number 32 Year of 2009 this is explicitly mentioned, then the consequence of this reverse evidentiary burden system must be taken as well. Law Number 32 Year 2009, on Environmental Protection and Management, also regulates in the case of a criminal act committed by a corporation, provided for in Article 116, reads: Article 116 paragraph (1)

If an environmental crime is committed by, for, or on behalf of a business entity, criminal prosecution and criminal sanctions are imposed on:

a. business entity; and / or

b. the person giving the order to commit the offense or the person acting as the leader of the activity in the offense. 


\section{Article 116 paragraph (2)}

If the environ mental crime as referred to in paragraph (1) is committed by a person, based on a work relationship or based on other relations acting within the scope of work of a business entity, a criminal sanction shall be imposed on the giver of an order or a leader in the offense regardless of the offense being committed alone or together.

Komar Kantaatmadja in his dissertation has advised that the provision of environmental legislation in general and pollution in particular, and all its implementation regulations, bears the principle of absolute responsibility as its core. As the reason stated that it is seen from the position of our State as an archipelagic State located between two oceans and two continents which is the inter transport of oil of giant countries in the Middle East and Japan industrialized countries as big consumers of petroleum, the estimate of the position of the State of the victim is an estimate most worrying that can be drawn from it. It is on this basis that in the future the oil spills from the tankers passing through the archipelago are still reckoned, although the rearrangement of the archipelages of the archipelago.Because the reasons for the difficulty to prove both of them and to be accountable is to take responsibility of absolute responsibility account for both direct and indirect losses incurred by the oil spill.

Komar Kataatmadja's statement is in accordance with the opinion of Kusnadi Hardjasoemantri, which states that given the vast territory of the $2 / 3$ archipelago is a marine environment, as well as the strategic geographical position (cross position between two Continents and two Oceans), the implementation of the strict liability principle is an effort and a move that can further safeguard the interests of Indonesia as an archipelagic country with its marine resources. Given the enormous benefits of this principle, it is natural that these principles of accountability and redress serve as the bas is for our national environmental legal system.

The use of the principle of "strict liability" is also not only used in sea pollution because of oil, but also applied in pollution to the environment itself. Accordingly, the inclusion of this principle into Law No. 32 of 2009 even though limited may be further expanded beyond that for the marine pollution already received in our national legal system.

Of the various formulations of environmental crimes in environmental legislation, are almost always listed intentional elements or forfeiture / negligence. With the existence of deliberate or negligent elements, it can be said that criminal liability in Law Number 32 Year 2009 on Environmental Protection and Management adheres to the principle of Liability based on fault. Thus, in principle, the principle of error or the principle of culpability.

Based on the principle of error, then in the criminal accountability as if no absolute liability is possible (often known as strict liability or absolute liability, although there is an opinion that the liability literature does not always mean the absolute liability). Theoretically it is possible to deviate from the principle of error, by using the principle of "strict liability" or "vicarious liability". Moreover it is not easy to prove the existence of errors in the delays of the living environment and errors in the corporation / legal entity.

\section{A. Criminal Sanctions Against Environmental Pollution and Destruction}

In the recent times we see almost every law that regulates a problem is always included the existence of criminal provisions. It is also found in Law No. 32 of 2009 on Environmental Protection and Management where there is specifically a chapter that contains criminal provisions (Chapter XV). The intention of stipulation of criminal provisions in this Act and also in other laws and regulations is only to support the implementati

Jaro Madya, argued that the criminal sanction is in nature as an "ultimum remedium". Criminal sanctions in the offense of environmental pollution may only be the only support to existing administrative sanctions as well as compensation claims that can be filed on the basis of losses suffered. In his opinion in the United States criminal prosecution is the end of a long chain aimed at eliminating or reducing adverse effects on the environment. The chain is grouped as follows:

a. Determination of policy, design and planning, statement of environmental impact.

b. Regulations on minimum standards or guidelines, licensing procedures.

c. Administrative decisions on violations, the determination of the grace period and the last day for the regulation to be observed.

d. Civil lawsuits to prevent or inhibit violations of judgments against fines or damages.

e. Public lawsuits to force or accelerate the government take action, indemnification lawsuit.

f. Criminal charges.

Initially in the old Law on Environmental Protection and Management (Law No. 4/1982) only used one type of sanction, namely the basic penal sanctions in the form of imprisonment, confinement and fine. Penalties and / or fines are threatened for environmental crimes in the form of "crimes", while for "offenses" are threatened with imprisonment and / or fines. Law No. 4 of 1982 does not mention any additional criminal and "action" sanctions. In its development, namely after the is suance of Law Number 32 Year 2009 on Environmental Protection and Management which replaces Law Number 23 of 1997 which replaces Law Number 4 Year 1982, known two types of sanctions that can be imposed on environmental criminal acts , that is:

\section{a. Criminal sanctions}

The types of criminal sanctions used only in the form of imprisonment and fine, there is no crime punishable by imprisonment. The absence of imprisonment may be due to all environmental crimes, pursuant to Law No. 32 of 2009 qualified as "crime". It should be noted, however, that according to the prevailing pattern (inside / outside the Criminal Code) it could be a crime threatened with impris onment.

b. Additional criminal sanctions or "regulatory acts" of disciplinary action that may be imposed on environmental offenders (persons / legal persons), in the form (Article 119):

1) Deprivation of profits derived from a crime;

2) Closing all or part of the place of business and / or activity;

3) Improvement due to crime;

4) The obligation to do what is neglected without rights; and / or 
5) Company placement under the maximum of 3 (three) years.

B. Comparison of Arrangements Between Law Number 23 Year 1997 By Law Number 32 Year 2009 on

Environmental Protection and Management.

Since October 3, 2009, Law No. 23/1997 on Environmental Management (UUPLH 1997) has been revoked and declared no longer valid, which was subsequently replaced by the presence of Law Number 32 Year 2009 on Environmental Protection and Management (UUPPLH 2009). In the UUPPLH 2009 consists of 17 chapters and 127 articles that regulate more thoroughly about Environmental Protection and Management. The fundamental difference between UUPLH 1997 and UUPPLH 2009 is the strengthening contained in UUPPLH 2009 on the principles of environmental protection and management based on good governance because in every process of formulation and application of pollution prevention and / or environmental degradation and prevention and law enforcement require the integration of good governance principles. These principles are community participation, enforcement of law supremacy, transparency, care for stakeholders, consensus-oriented, equity, effectiveness and efficiency, accountability, and strategic vision.[7].

According to Koesnadi Hardjasoemantri, to run the good governance, then all the principles of good governance should be pursued by the government bureaucracy. Therefore, these principles should be the guidelines of the bureaucracy in carrying out its duties for public service [8]. Please note, some of the most important points in Law Number 32 Year of 2009 on Environmental Protection and Management (UUPPLH2009) among others [9]:

1. The integrity of elements of environmental management;

2. Clarity of authority between the central and regional governments;

3. Strengthening on environmental control efforts;

4. Strengthening of pollution prevention and / or environmental damage instruments, including strategic environmental assessment instruments, spatial planning, environmental quality standards, environmental damage criteria, AMDAL, environmental management efforts and environmental monitoring efforts, licensing, instruments environmental economics, environmental-based legislation, environmental-based budgeting, environmental risk analysis, and other instruments relevant to the development of science and technology;

5. Utilization of licensing as a control instrument;

6. Utilization of ecosystem approaches; Certainty in responding to and anticipating the development of the global environment;

7. Strengthening environmental democracy through access to information, access to participation, and access to justice and the strengthening of community rights in the protection and management of the environment;
8. Enforcing civil, administrative, and criminal law more clearly;

9. Strengthening the institutional safeguards and management of the environment more effectively and responsively; and

10. Enforcement of the authority of the Environmental Supervisory Officer and the Environmental Civil Servant Investigator.

UUPPLH 2009 gives wide authority to the Minister to implement all government authorities in the field of Environmental Protection and Management (PPLH) and coordinate with other agencies. Through the UUPPLH 2009, the Government gives wide authority to local governments in protecting and managing the environment in their respective regions which are not regulated in Law No. 23 of 1997 on Environmental Management (UUPLH 1997). In the third part of UUPPLH, regulated on the preparation of Environmental Protection and Management Plan (RPPLH). This provision is to provide wide authority to local governments for environmental protection and management. RPPLH consis ts of National RPPLH, Provincial RPPLH, and RPPLH regency / City. Article $10 \mathrm{UUPPLH}$ authorizes to make RPPLH as referred to in Article 9 compiled by the Minister, Governor, or Regent / Mayor in accordance with their authority. Preparation of the RPPLH based on the authority should pay attention to:
a. Diversity of ecological character and function
b. Population distribution;
c. Distribution of potential natural resources;
d. Local wisdom;
e. People's aspirations; and
f. Climate change.

Therefore, an agency that has a workload under UUPPLH 2009 is not enough just an organization that establishes and coordinates the implementation of the policy, but it takes an organization with a portfolio establishing, implementing, supervising the protection policy, and environmental management. In addition, the institute also has the scope of authority to oversee natural resources for conservation purposes.

To ensure that the main duties and functions of the institution are required, adequate funding support from the State Budget (APBN) for adequate Government and Regional Revenue and Expenditure for Local Government is required. In the UUPPLH 2009 as a substitute of UUPLH 1997, the definition of Protection and Environmental Management (PPLH) in the Act include:

1. Aspects of planning undertaken through environmental inventory, establishment of ecoregion areas and preparation of the RPPLH (Environ mental Protection and Management Plan).

2. Aspects of natural resource utilization based on RPPLH. In the UUPPLH 2009 it has been arranged that if an area has not compiled RPPLH then the utilization of natural resources is carried out based on the carrying capacity and the capacity of the environment.

3. Aspects of control over pollution and damage to environmental functions which include prevention, overcoming and recovery. 
In the UUPPLH 2009 also included the arrangement of several new control instruments, including: Strategic Environmental Assessment (KLHS), spatial layout, environmental damage criteria, Environmental Impact Assessment (AMDAL), Environmental Management Efforts and Environmental Monitoring Effort (UKL -UPL), licensing, environmental economic instruments, environmental-based legislation, environment-based budgets, environmental risk analysis, environmental audits, and other instruments in accordance with the needs and / or development of science. This was not previously regulated in UUPLH 1997.

In UUPPLH 2009, it also regulates the maintenance of the environment through conservation of natural resources, natural resources reserves, and / or the preservation of atmospheric functions. Aspects of supervision and law enforcement, including. Strict penalty (criminal and civil) sanctions for violations of the quality standards, AMDAL violators (including officers issuing permits without AMDAL or UKL-UPL), breach and dissemination of genetically engineered, non-licensed, dumping without permits, putting waste into Unitary State of the Republic of Indonesia (NKRI) without permission, burning forests, arranging environmental supervisors, and Civil Service Investigator(PPNS) to make them functional.

There are articles governing criminal and civil sanctions that threaten any violation of regulations in the field of environmental protection and management, whether to individuals, corporations, or officials. For example, a violation of the quality standard shall be imprisoned with a minimu m imp risonment of 3 (three) years and a maximu $m$ of 10 (ten) years and a fine of at least Rp.3.000.000.000,00 (three billion rupiah) and a maximum of Rp. 10,000,000,000.00 (ten billion rupiahs).

The Environmental Impact Assessment (AMDAL) in UUPPLH 2009 gets a considerable portion compared to other environmental instruments, out of 127 existing articles, 23 articles of which regulate AMDAL. But the definition of AMDAL in UUPPLH 2009 is different from the definition of AMDAL in UUPLH 1997, the difference is the loss of "big impact". If in UUPLH 1997 it states that, "Environmental Impact Assessment (AMDAL) is a study of the major and significant impacts of a planned business and / or activity on the environment necessary for the decision-making process on the conduct of business andlor activity" UUPPLH 2009 states that, "Environmental Impact Assessment (AMDAL), is a study of the significant impacts of a planned business and / or activity on the environment necessary for the decisionmaking process on the conduct of business andlor activities".

Of the 23 Articles, there are important articles not previously contained in Law No. 23 of 1997 (UUPLH 1997) and Government Regulation No. 27 of 1999 and have major implications for AMDAL actors, including licensing officials. Important new issues related to AMDAL are contained in UUPPLH 2009, which are not regulated in UUPLH 1997, among others:

1. AMDAL and UKL-UPL is one of the instruments of prevention of pollution and / or environmental damage;

2. Preparation of AMDAL documents must have competency certificates for the AMDAL document;
3. The AMDAL Central, Provincial, or District / City AMDAL as sessment committees are required to have an AMDAL license;

4. AMDAL and UKL-UPL are requirements for the is suance of environmental permits;

5. Environmental permit issued by the Minister, Governor, Regent / Mayor in accordance with their authority.

In addition to the above mentioned five, there are strict regulations mandated in the UUPPLH 2009, which is subject to criminal and civil sanctions related violations of AMDAL. The articles governing the sanctions are as follows:

a. Sanctions against persons conducting business / activities without having an environmental permit

b. Sanctions against persons who prepare EIA documents without having a competency certificate;

c. Sanctions against officials who grant environmental permits that are not equipped with AMDAL or UKLUPL documents.

\section{CONCLUSION}

It is required for businessmen engaged in the field of industry in the production process should pay attention in environmental issues. Along with the importance of a healthy environment is the right of all human beings, so that corporations that conduct business activities to preserve the environment, therefore no one feels aggrieved it is necessary to make improvements in the criminal system against the formulation of every legislation regarding Environmental Pollution to whom which shall be liable to sanctions against the Corporation, the Board of Directors or any Person who commits a criminal act of Environmental Pollution.

A complete laboratory is required to conduct tests on environmental pollution in each province. There needs to be an increase and professional ability of law enforcement officers (Police, Prosecutors, Judges) on matters related to environmental crime handling.

Should the Central Government through the Ministry of Environment and Forestry in cooperation with the Regional Government and related agencies have to work extra in the supervision of the Environmental Corporations by providing continuous, efficient and integrated coaching in the hope of reducing the percentage of environmental crimes committed by corporation.

\section{REFERENCES}

[1] S. P. Hadi, DimensiHukum Pembangunan Berkelanjutan, 1st ed. Semarang: UNDIP, 2002.

[2] Haryono and W. Suwarty, Hukum Lingkungan. Jakarta: Sinar Surya Megah Perkasa, 2011.

[3] Priyatno, No Title. 2004

[4] C. Ryan, Criminal Law, 5th ed. London: Blackstone Press Limited, 1998.

[5] Allen, No Title. 1998.

[6] Fleming. J.G, The Law of Tort. 1998.

[7] Nasution, No Title. 2003.

[8] K. Hardjasoemantri, "Good Governance Dalam Pembangunan Berkelanjutan Di Indonesia,” 2003.

[9] Suliastini, No Title. 2009. 